\title{
PENGARUH LATIHAN CIRCUIT TRAINING TERHADAP PENINGKATAN DAYA TAHAN AEROBIK PEMAIN SEPAKBOLA UNIVERSITAS BINA DARMA
}

\author{
M. Haris Satria \\ Universitas Bina Darma \\ Jalan Ahmad Yani No.3 Palembang \\ Sur-el: mharis_satria@yahoo.com
}

Article info

Article history:

Received: $15 / 04 / 2018$

Revised : 16/04/2018

Accepted: 25/05/2018

Keywords:

circuit

training,endurance,

football

Kata Kunci:

circuit training, daya tahan tubuh,

sepakbola

\begin{abstract}
A B S T R A C T
This study aimed to determine the Effect of Circuit Training Exercises to increase the Aerobic Endurance of Bina Darma University Football Players. This type of research is experimental research. The study sample amounted to 17 people. The instrument used was the BLEP test. The data analysis technique used SPSS statistics 23. The result of this study indicated that circuit training exercise can increase the aerobic endurance of Bina Darma University soccer players. The t test showed that $t_{-}$(count) $=6,564>t_{-}($table $)=1,740$ so that the accepted $\mathrm{Ha}$ is significant. Suggestion from this research is that trainers can use the circuit training method to increase the aerobic endurance of athletes.
\end{abstract}

Penelitian ini bertujuan untuk mengetahui Pengaruh Latihan Circuit Training terhadap Peningkatan Daya Tahan Aerobik Pemain Sepakbola Universitas Bina Darma. Jenis penelitian ini yaitu penelitian eksperimen. Sampel penelitian berjumlah 17 orang. Instrumen yang digunakan adalah blepp test. Teknik analisis data mengguunakan SPSS statistics 23. Hasil penelitian ini menunjukan bahwa latihan circuit training dapat meningkatkan daya tahan aerobik pemain sepakbola Universitas Bina Darma. Uji t menunjukkan bahwa sehingga $\boldsymbol{t}_{\text {hitung }}=6.564>\boldsymbol{t}_{\text {tabel }}=1.740$ sehingga terima Ha dengan signifikan. Saran dari penelitian ini yaitu para pelatih dapat menggunakan metode latihan circuit training untuk meningkatkan daya tahan aerobik atletnya.

Direktorat Riset dan Pengabdian Masyarakat Universitas Bina Darma.

\section{PENDAHULUAN}

Sepakbola merupakan olahraga permainan beregu yang terdiri dua tim dimana masingmasing tim terdiri dari sebelas pemain yang bertujuan memasukkan bola ke dalam gawang dengan cara menyepak bola. Setiap pemain dilarang memegang bola kecuali penjaga gawang. 


\section{JURNAL ILMIAH \\ BINA EDUKASI \\ ISSN 1979-8598 \\ http://journal.binadarma.ac.id/index.php/jurnalbinaedukasi \\ Vol. 11, No. 1, Juni 2018, 36-48}

Tim yang menang adalah yang dapat memasukkan bola lebih banyak dibandingkan dengan tim lawan. Hal ini sejalan dengan pendapat dari Sucipto (2000:7) yaitu :

"Sepakbola merupakan permainan beregu, masing-masing regu terdiri dari sebelas pemain, dan salah satunya penjaga gawang. Permainan ini hampir seluruhnya dimainkan menggunakan tungkai, kecuali penjaga gawang yang dibolehkan menggunakan lengannya di daerah tendangan hukuman. Tujuan dalam permainan ini yaitu pemain memasukkan bola sebanyak-banyaknya ke gawang lawannya dan berusaha menjaga gawangnya sendiri, agar tidak kemasukkan".

Selanjutnya menurut Muhajir (2006: 1), sepakbola adalah suatu permainan yang dilakukan dengan jalan menyepak bola, dengan tujuan memasukan bola ke gawang lawan dan mempertahankan gawang tersebut agar tidak kemasukkan bola. Bermain sepakbola harus menguasai beberapa teknik dasar seperti menendang, menggiring bola, mengontrol bola dan menyundul bola. Menurut Mielke (2007:1) kemampuan dasar bermain sepakbola yang harus dikuasai antara lain adalah menggiring (dribbling), mengoper (passing), menembak (shooting), menyundul bola (heading), menimang bola (juggling), menghentikan bola (trapping), dan lemparan ke dalam (throw-in).

Bermain sepakbola dituntut memiliki kondisi fisik yang prima dikarenakan bermain sepakbola cukup lama yaitu selama 90 menit, waktu tersebut belum ditambah extra time jika kedudukan masih tetap seimbang. Kondisi fisik yang perlu dimiliki pemain sepakbola diantaranya adalah daya tahan aerobik/Vo2 Mak (endurance).

Daya tahan aerobik adalah kemampuan sistem jantung-paru dan pembuluh darah untuk berfungsi secara optimal pada saat melakukan aktivitas sehari-hari dalam waktu yang cukup lama tanpa mengalami kelelahan yang berarti (Wahjoedi, 2001: 59). Menurut Djoko Pekik Irianto, dkk. (2007: 72) daya tahan aerobik dapat diartikan sebagai daya tahan seluruh tubuh yang dibutuhkan untuk bisa menyelesaikan lari jarak jauh, renang jarak jauh, dan bersepeda jarak jauh. Pendapat ini sejalan dengan pendapat Husein Argasasmita, dkk. (2007: 65) yang mengatakana bahwa daya tahan aerobik dapat disebut aerobik fitness dimana proses kegiatan atau aktivitas memerlukan oksigen karena digunakan dalam jangka yang lama, seperti lari jarak jauh, bersepeda dan lain-lain.

Selanjutnya menurut Depdiknas (2000: 53) bahwa daya tahan aerobik merupakan kemampuan sistem peredaran darah dan sistem pernafasan untuk menyesuaikan diri terhadap efek seluruh beban kerja fisik. Dengan melakukan aktivitas gerak dan olahraga yang teratur dan sistematis akan dapat meningkatkan kualitas sistem jantung dan paru

Setiap orang memiliki daya tahan yang berbeda-beda antara yang satu dan lainnya. Menurut Fox dalam Sukadiyanto (2011: 64) faktot-faktor yang dapat mempengaruhi daya tahan adalah (1) itensitas, (2) frekuensi, (3) durasi latihan, (4) faktor keturunan, (5) usia, dan (6) jenis kelamin. Selanjutnya Menurut Depdiknas (2000: 54) faktor-faktor yang mempengaruhi daya 


\section{JURNAL ILMIAH \\ BINA EDUKASI \\ ISSN 1979-8598 \\ http://journal.binadarma.ac.id/index.php/jurnalbinaedukasi \\ Vol. 11, No. 1, Juni 2018, 36-48}

tahan yaitu (1) keturunan/genetik : Faktor genetik yang berperan dapat membedakan kapasitas jantung, paru-paru, sel darah merah dan hemoglobin, (2) umur : Mulai dari anak-anak sampai umur 20 tahun, daya tahan aerobik meningkat, mencapai maksimal pada umur 20-30 tahun dan kemudian berbanding terbalik dengan umur, sehingga pada orang yang berumur 70 tahun diperoleh daya tahan $50 \%$ dari yang dimilikinya pada umur 17 tahun, (3) jenis kelamin : Sampai dengan umur pubertas tidak terdapat perbedaan daya tahan aerobik antara pria dan wanita. Setelah umur tersebut nilai pada wanita lebih rendah $15-25 \%$ dari pada pria. Perbedaan tersebut disebabkan oleh adanya komposisi tubuh, kekuatan otot, jumlah hemoglobin, dan kapasitas paru jantung, dan (4) aktivitas fisik : aktivitas fisik akan mempengaruhi nilai daya tahan aerobik. Seseorang yang melakukan lari jarak jauh mempunyai daya tahan kardiovaskuler lebih tinggi.

Seseorang yang memiliki tingkat daya tahan yang baik, maka otot-ototnya akan mendapat suplai bahan bakar dan oksigen yang cukup besar, mempunyai denyut nadi cenderung lebih lambat, paru-paru dapat mensuplai darah merah lebih banyak keseluruh jaringan-jaringan tubuh, dan cenderung tidak cepat lelah.

Meningkatkan daya tahan aerobik dapat ditingkatkan melalui latihan. Latihan adalah proses yang sistematis dari berlatih atau kerja, yang dilakukan secara berulang-ulang, dengan kian hari kian menambah jumlah beban latihan atau pekerjaannya (Harsono, 1988:101). Menurut Bompa (1986:4) latihan adalah aktifitas olahraga yang sistematis dalam waktu yang panjang, ditingkatkan secara progresif dan individual, mengarah pada ciri fungsi fisiologis manusia untuk mencapai sasaran yang ditentukan. Selanjutnya, menurut Kokasih (1985:46 ) latihan adalah proses kerja yang harus dilakukan secara sistematis, berulang-ulang, dan jumlah beban yang diberikan semakin hari semakin bertambah.

Dari beberapa pengertian di atas dapat peneliti simpulkan bahwa yang dimaksud latihan adalah proses sistematis dalam waktu yang lama, untuk meningkatkan kemampuan fisik seseorang dengan berpegang pada prinsip latihan untuk mencapai target atau tujuan yang telah ditetapkan.

Latihan yang baik harus dilaksanakan secara sistematis, teratur, terencana dan berkesinambungan. Hal ini sejalan dengan prinsip-prinsip latihan antara lain prinsip kesiapan (Readiness), prinsip individual, prinsip adaptasi, prinsip beban lebih (Overload), prinsip progresif (Peningkatan), prinsip spesifikasi (Kekhususan), prinsip variasi, prinsip pemanasan dan pendinginan (Warm-Up and Cool Down), prinsip jangka panjang (Long Term Training), prinsip berkebalikan (Reversibility), prinsip tidak berlebih (Moderat), prinsip sistematik (Mylsidayu, 2015: 55-64). Menurut Djoko Pekik Irianto (2002: 43-51) prinsip-prinsip latihan antara lain prinsip beban lebih (Overload), prinsip kembali asal (Reversible), prinsip kekhususan (specifity), prinsip individual, prinsip beragam, prinsip keterlibatan aktif. 


\section{JURNAL ILMIAH \\ BINA EDUKASI \\ ISSN 1979-8598 \\ http://journal.binadarma.ac.id/index.php/jurnalbinaedukasi \\ Vol. 11, No. 1, Juni 2018, 36-48}

Metode sirkuit biasanya terdiri dari beberapa item (macam) latihan yang harus dilakukan dalam waktu tertentu. Setelah selesai pada satu item latihan segera pindah pada item yang lain, demikian seterusnya sampai seluruh item latihan selesai dilakukan, sehingga disebut telah melakukan satu sirkuit. Menurut Muhajir (2007: 58), circuit training adalah urutan latihan dengan satu macam kegiatan di setiap pos antara 4-12 pos. Olahragawan bebas untuk memulai latihan dari mana saja. Untuk itu dalam menyusun urutan item latihan diusahakan sasaran otot yang ditingkatkan berseling. Artinya otot yang dikenai beban latihan berganti-ganti pada setiap item latihan.

Dampak dari latihan dapat terlihat setelah menjalani latihan selama 6-8 minggu. Menurut Muhajir (2004:3) berpendapat bahwa seorang atlet yang mengikuti program latihan kondisi fisik secara intensif selama 6-8 minggu sebelum musim pertandingan, akan memiliki kekuatan, kelentukan dan daya tahan yang jauh lebih baik selama musim pertandingan. Pendapat tersebut diperkuat oleh Sumosardjono (1987:11) berpendapat bahwa :

"bila latihan telah berlangsung dalam jangka cukup lama, paling sedikit 4-8 minggu, dan anda berlatih secara teratur dengan takaran waktu yang cukup, maka terjadilah efek latihan (training effect)".

Latihan untuk meningkatkan daya tahan aerobik salah satunya yaitu melalui latihan cirkuit training. Menurut Suharjana (2013: 70) latihan sirkuit adalah suatu bentuk atau model atau metode dalam suatu program latihan terdiri dari beberapa stasiun atau pos dan di setiap stasiun seorang atlet melakukan jenis latihan yang telah ditentukan. Program latihan sirkuit dilakukan 8 stasiun tempat latihan. Setiap stasiun terdiri dari suatu latihan yang dilakukan selama 45 detik, dan repetisi latihan antara 15-20 kali, waktu istirahat dalam satu stasiun sebelum berpindah kestasiun berikutnya adalah 1 menit atau kurang J.P O'Shea dalam Sajoto (200: 163).

Menurut E.L. Fox yang dikutip oleh Sajoto (2000: 163) program latihan sirkuit dilakukan dengan 6-15 stasiun tempat latihan. Satu latihan dalam satu stasiun diselesaikan dalam 30 detik. Satu sirkuit diselesaikan antara 5-20 menit, dengan waktu istirahat tiap stasiun adalah 15-20 detik. Menurut Sajoto (2000: 165) program latihan sirkuit harus dirancang untuk peningkatan kemampuan fisiologi pada kekuatan otot, power, endurance otot, flexibilitas, dan cardiorespiratory endurance.

Berdasarkan hasil observasi peneliti pada pemain sepakbola Universitas Bina Darma didapat bahwa daya tahan tubuh (aerobik) mereka masih terlihat rendah. Hal ini terlihat saat mereka bermain maupun bertanding dimana nafas mereka sudah mulai terengah-engah padahal baru memasuki 15 menit pertama babak pertama, selanjutnya memasuki 15 menit kedua babak pertama, terlihat beberapa pemain mulai malas untuk mengejar bola dan memasuki 15 menit terakhir pemain lebih banyak berjalan. Hal ini juga berulang ke babak kedua pertandingan. 


\section{JURNAL ILMIAH \\ BINA EDUKASI \\ ISSN 1979-8598 \\ http://journal.binadarma.ac.id/index.php/jurnalbinaedukasi \\ Vol. 11, No. 1, Juni 2018, 36-48}

Dari observasi tersebut, peneliti melakukan kajian yang lebih mendalam untuk melihat kemampuan daya tahan aerobik pemain sepakbola Universitas Bina Darma. Kajian tersebut berpedoman kepada lembar pengamatan yang telah disusun oleh peneliti berdasarkan pedoman dasar penilaian tingkat daya tahan aerobik. Dari hasil kajian tersebut diperoleh hasil bahwa kemampuan daya tahan aerobik masih kurang.

Berangkat dari permasalahan di atas maka peneliti tertarik untuk melakukan penelitian dengan mengangkat judul "Pengaruh Latihan Circuit Training Terhadap Peningkatan Daya Tahan Aerobik Pemain Sepakbola Universitas Bina Darma". Tujuan dari penelitian ini yaitu untuk mengetahui pengaruh latihan circuit training terhadap daya tahan aerobik.

\section{METODOLOGI PENELITIAN}

\subsection{Jenis Penelitian}

Jenis penelitian yang digunakan dalam penelitian ini adalah jenis atau metode eksperimen menggunakan rancangan one group pretest posttest design. Menurut Ali Maksum (2012:97) yang dimaksud one group pretest posttest design adalah penelitian yang tidak ada kelompok kontrol dan subjek tidak ditempatkan secara acak. Dalam desain ini hanya terdapat satu kelompok, yaitu dimana hanya diberi tes awal kemudian diberi treatment atau perlakuan dan terakhir diberi tes akhir.

Dalam penelitian ini tes dilakukan sebanyak dua kali yaitu pretest (tes awal) dan postest (tes akhir). Perbedaan antara pretest (tes awal) dan postest (tes akhir) ini diasumsikan sebagai efek dari treatment atau perlakuan.

\subsection{Rancangan Penelitian}

Penelitian ini termasuk penelitian eksperimen. Hal ini dikarenakan tes yang dilakukan bertujuan mengetahui sejauh mana pengaruh latihan circuit training yaitu varibel bebas (X) terhadap peningkatan daya tahan aerobik yaitu varibel terikat (Y).

$$
\mathrm{O}_{1} \rightarrow \mathrm{X} \rightarrow \mathrm{O}_{2}
$$

Sumber: Maksum (2012:97)

Gambar 1. Rancangan Penelitian 
Keterangan:

$\mathrm{O}_{1}$ : Pretest

$\mathrm{X}$ : Treatment/Perlakuan

$\mathrm{O}_{2}$ : Postest

\subsection{Tempat dan Waktu Penelitian}

Penelitian dilakukan di lapangan Sekolah Olahraga Negeri Sriwijaya (SONS). Sumatera Selatan Waktu penelitian dilakukan hari Senin, Rabu dan Jumat pukul 16.00 WIB - 18.00 WIB.

\subsection{Populasi dan Sampel}

Populasi adalah keseluruhan subjek penelitian, (Arikunto, 2006: 130). Keseluruhan yang menjadi sasaran dalam penelitian ini adalah pemain sepakbola Universitas Bina Darma yang berjumlah 17 orang.

Arikunto (2006: 131) mengatakan bahwa sampel adalah sebagian atau wakil populasi yang diteliti. "Untuk sekedar ecer-ecer, maka apabila subjeknya kurang dari 100, maka lebih baik diambil semua sehingga penelitiannya merupakan penelitian populasi. Tetapi, jika jumlah subjeknya besar, dapat diambil antara $10-15 \%$ atau $20-25 \%$ atau lebih".

Berdasarkan pendapat ahli di atas maka sampel yang diambil dalam penelitian ini adalah pemain sepakbola Universitas Bina Darma yang berjumlah 17 orang.

\subsection{Variabel Penelitian}

Varibel dalam penelitian ini terdiri dari dua variabel yaitu variabel independen (variabel bebas) dan variabel dependen (variabel terikat), untuk lebih jelasnya sebagai berikut

1) Latihan latihan circuit training merupakan variabel independen (varibel bebas) yang dilambangkan (X)

2) Daya tahan aerobik merupakan variabel dependen (varibel terikat) yang dilambangkan (Y)

\subsection{Instrumen Penelitian}

Instrument penelitian adalah suatu alat yang digunakan mengukur fenomena alam maupun sosial yang diamati (Sugiyono, 2012: 148). Tes yang akan digunakan untuk mengukur 


\section{JURNAL ILMIAH}

BINA EDUKASI

ISSN 1979-8598

http://journal.binadarma.ac.id/index.php/jurnalbinaedukasi

Vol. 11, No. 1, Juni 2018, 36-48

peningkatan daya tahan aerobik pemain sepakbola Universitas Bina Darma yaitu blepp test (Widiastuti, 2015:71)

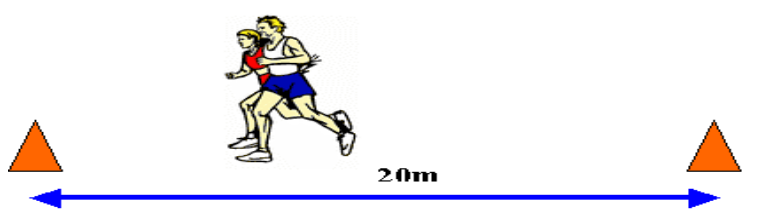

\section{Gambar 2. Lintasan Bleep Test}

\begin{tabular}{|c|c|c|c|c|c|c|c|c|c|c|c|c|c|c|c|}
\hline \multicolumn{16}{|c|}{ Beep Test Score Sheet } \\
\hline \multicolumn{8}{|c|}{ Enter contestant name below } & \multicolumn{7}{|c|}{ Enter contest date below } & \\
\hline Stage & \multicolumn{13}{|c|}{$\begin{array}{l}\text { Place a cross through each run number as the } \\
\text { contestant completes each run before the 'beep' signal. }\end{array}$} & & \\
\hline 1 & 1 & 2 & 3 & 4 & 5 & 6 & 7 & & & & & & & & \\
\hline 2 & 1 & 2 & 3 & 4 & 5 & 6 & 7 & & & & & & & & \\
\hline 3 & 1 & 2 & 3 & 4 & 5 & 6 & 7 & 8 & & & & & & & \\
\hline 4 & 1 & 2 & 3 & 4 & 5 & 6 & 7 & 8 & & & & & & & \\
\hline 5 & 1 & 2 & 3 & 4 & 5 & 6 & 7 & 8 & & & & & & & \\
\hline 6 & 1 & 2 & 3 & 4 & 5 & 6 & 7 & 8 & 9 & & & & & & \\
\hline 7 & 1 & 2 & 3 & 4 & 5 & 6 & 7 & 8 & 9 & & & & & & \\
\hline 8 & 1 & 2 & 3 & 4 & 5 & 6 & 7 & 8 & 9 & 10 & & & & & \\
\hline 9 & 1 & 2 & 3 & 4 & 5 & 6 & 7 & 8 & 9 & 10 & & & & & \\
\hline 10 & 1 & 2 & 3 & 4 & 5 & 6 & 7 & 8 & 9 & 10 & & & & & \\
\hline 11 & 1 & 2 & 3 & 4 & 5 & 6 & 7 & 8 & 9 & 10 & 11 & & & & \\
\hline 12 & 1 & 2 & 3 & 4 & 5 & 6 & 7 & 8 & 9 & 10 & 11 & & & & \\
\hline 13 & 1 & 2 & 3 & 4 & 5 & 6 & 7 & 8 & 9 & 10 & 11 & 12 & & & \\
\hline 14 & 1 & 2 & 3 & 4 & 5 & 6 & 7 & 8 & 9 & 10 & 11 & 12 & & & \\
\hline 15 & 1 & 2 & 3 & 4 & 5 & 6 & 7 & 8 & 9 & 10 & 11 & 12 & & & \\
\hline 16 & 1 & 2 & 3 & 4 & 5 & 6 & 7 & 8 & 9 & 10 & 11 & 12 & 13 & & \\
\hline 17 & 1 & 2 & 3 & 4 & 5 & 6 & 7 & 8 & 9 & 10 & \begin{tabular}{|l|}
11 \\
\end{tabular} & 12 & 13 & & \\
\hline 18 & 1 & 2 & 3 & 4 & 5 & 6 & 7 & 8 & 9 & 10 & 11 & 12 & $\begin{array}{ll}13 \\
\end{array}$ & 14 & \\
\hline 19 & 1 & 2 & 3 & 4 & 5 & 6 & 7 & 8 & 9 & 10 & 11 & 12 & 13 & 14 & \\
\hline 20 & 1 & 2 & 3 & 4 & 5 & 6 & 7 & 8 & 9 & 10 & 11 & 12 & \begin{tabular}{l|}
13 \\
\end{tabular} & 14 & \\
\hline
\end{tabular}

Gambar 3. Score Sheet Bleep Test

\begin{tabular}{|c|c|}
\hline $\begin{array}{l}\text { Completed } \\
\text { Level }\end{array}$ & $\begin{array}{l}\text { Estimated } \\
\text { W02 max }\end{array}$ \\
\hline 1 & 23.5 \\
\hline 2 & 23.9 \\
\hline 3 & 26.7 \\
\hline 4 & 29.8 \\
\hline 5 & 32.9 \\
\hline 6 & 36.0 \\
\hline 7 & 39.6 \\
\hline 8 & 42.8 \\
\hline 9 & 46.6 \\
\hline 10 & 49.9 \\
\hline 11 & 53.5 \\
\hline 12 & 57.0 \\
\hline 13 & 60.4 \\
\hline 14 & 64.2 \\
\hline 15 & 67.6 \\
\hline 16 & 71.2 \\
\hline 17 & 74.6 \\
\hline 18 & 77.9 \\
\hline 19 & 81.4 \\
\hline 20 & 84.6 \\
\hline 21 & 88.1 \\
\hline 22 & 91.1 \\
\hline 23 & 94.0 \\
\hline
\end{tabular}

Gambar 4. Level Bleep Test 


\begin{tabular}{|c|c|c|c|c|}
\hline \multicolumn{5}{|c|}{ ale V02 max norms (mlikgimin) } \\
\hline Aye & Fair & Good & Very Good & Excellent \\
\hline $13 \cdot 19$ & $38.4 \cdot 45.1$ & 45.2 .50 .9 & $51.0 \cdot 55.9$ & $>55.9$ \\
\hline 20.29 & $36.5 \cdot 42.4$ & $42.5 \cdot 46.4$ & $46.5 \cdot 52.4$ & 352.4 \\
\hline 30.39 & 35.5 .40 .9 & $41.0 \cdot 44.9$ & $45.0 \cdot 49.4$ & $>49.4$ \\
\hline $40 \cdot 49$ & 33.6 .38 .9 & $39.0 \cdot 43.7$ & $43.8 \cdot 48.0$ & $>48.0$ \\
\hline 50.59 & $31.0 \cdot 35.7$ & $35.8 \cdot 40.9$ & $41.0 \cdot 45.3$ & $>45.3$ \\
\hline $60+$ & 26.1 .32 .2 & $32.3 \cdot 36.4$ & $36.5 \cdot 44.2$ & $>44.2$ \\
\hline
\end{tabular}

Gambar 5. Norma Test

\subsection{Hipotesis Penelitian}

Hipotesis merupakan suatu jawaban sementara yang terhadap rumusan masalah penelitian, di mana rumusan masalah penelitian telah dinyatakan dalam bentuk kalimat pertanyaan (Sugiyono, 2011:64) Hipotesis dalam penelitian ini mengemukakan bahwa :

1. $\mathrm{Ha}=$ Terdapat pengaruh yang signifikan dari latihan circuit training terhadap peningkatan daya tahan aerobik pemain sepakbola Universitas Bina Darma.

2. Ho $=$ Tidak terdapat pengaruh yang signifikan dari latihan circuit training terhadap peningkatan daya tahan aerobik pemain sepakbola Universitas Bina Darma.

\subsection{Teknik Analisis Data}

Teknik analisis data dalam penelitian ini yaitu uji $t(t-t e s t)$. Uji $t$ tersebut menggunakan SPSS statistic 23.

\section{HASIL DAN PEMBAHASAN}

\subsection{Deskripsi Tempat Penelitian}

Penelitian ini dilakukan di lapangan sepakbola Sekolah Olahraga Negeri Sriwijaya (SONS) Sumatera Selatan. Sampel penelitian ini adalah pemain sepakbola Universita Bina Darma sebanyak 17 orang, dengan menggunakan rancangan one-group, pretest, posttest, design. Dalam penelitian ini tes diberikan sebanyak dua kali tes yaitu tes awal 


\section{JURNAL ILMIAH}

BINA EDUKASI

ISSN 1979-8598

http://journal.binadarma.ac.id/index.php/jurnalbinaedukasi

Vol. 11, No. 1, Juni 2018, 36-48

(pretest) dan tes akhir (postest). Seluruh mahasiswa melakukan tes awal (pretest) yaitu bleep test, setelah dapat hasil tes awal maka mereka diberikan perlakuan. Perlakuan terhadap mereka yaitu latihan circuit training, setelah diberikan latihan circuit training selama 6 minggu dengan latihan 3 kali dalam seminggu maka mereka dites akhir. Tes akhirnya juga sama yaitu blepp test. Kemudian dilakukan perbandingan antara test awal dengan test akhir setelah perlakuan.

\subsection{Deskripsi Data Penelitian}

Berikut adalah deskripsi data hasil pretest (tes awal) daya tahan aerobik :

Tabel 1. Data Hasil Tes Awal

\begin{tabular}{|c|c|}
\hline Peserta Tes & Hasil Tes Awal \\
\hline $\mathrm{X} 1$ & 41.80 \\
\hline $\mathrm{X} 2$ & 37.45 \\
\hline $\mathrm{X} 3$ & 37.45 \\
\hline $\mathrm{X} 4$ & 38.15 \\
\hline $\mathrm{X} 5$ & 40.50 \\
\hline X6 & 43.00 \\
\hline$X 7$ & 39.55 \\
\hline $\mathrm{X} 8$ & 41.80 \\
\hline X9 & 42.10 \\
\hline $\mathrm{X} 10$ & 40.50 \\
\hline $\mathrm{X} 11$ & 39.90 \\
\hline $\mathrm{X} 12$ & 40.20 \\
\hline $\mathrm{X} 13$ & 39.20 \\
\hline $\mathrm{X} 14$ & 43.60 \\
\hline $\mathrm{X} 15$ & 41.45 \\
\hline $\mathrm{X} 16$ & 41.80 \\
\hline $\mathrm{X} 17$ & 39.90 \\
\hline
\end{tabular}

Data di atas menunjukkan hasil terendah tes awal daya tahan aerobik yaitu 37.45 sedangkan hasil tertinggi tes awal yaitu 43.00. selanjutnya deskripsi data hasil tes akhir yaitu : 
ISSN 1979-8598

http://journal.binadarma.ac.id/index.php/jurnalbinaedukasi

Vol. 11, No. 1, Juni 2018, 36- 48

Tabel 2. Data Hasil Tes Akhir

\begin{tabular}{cc}
\hline Peserta Tes & Hasil Tes Awal \\
\hline X1 & 43.00 \\
X2 & 41.45 \\
X3 & 42.70 \\
X4 & 40.80 \\
X5 & 42.70 \\
X6 & 45.20 \\
X7 & 40.80 \\
X8 & 42.10 \\
X9 & 44.50 \\
X10 & 42.10 \\
X11 & 41.10 \\
X12 & 42.70 \\
X13 & 41.45 \\
X14 & 43.90 \\
X15 & 43.00 \\
X16 & 42.70 \\
X17 & 41.80 \\
\hline
\end{tabular}

Data di atas menunjukkan hasil terendah tes akhir daya tahan aerobik yaitu 41.10 sedangkan hasil tertinggi tes awal yaitu 45.20.

\subsection{Hasil Uji Hipotesis}

Uji hipotesis (uji t) dihitung menggunakan SPSS statistic 23. Hipotesis yang diuji sebagai berikut.

Ho : tidak terdapat pengaruh latihan circuit training terhadap peningkatan daya tahan aerobik pemain sepakbola Universitas Bina Darma, jika $t_{\text {hitung }}<t_{\text {tabel }}$ maka Ho diterima dan Ha ditolak.

Ha : terdapat pengaruh latihan circuit training terhadap peningkatan daya tahan aerobik pemain sepakbola Universitas Bina Darma, jika $t_{\text {hitung }} \geq t_{\text {tabel }}$ maka Ho ditolak dan Ha diterima. 


\section{JURNAL ILMIAH \\ BINA EDUKASI \\ ISSN 1979-8598 \\ http://journal.binadarma.ac.id/index.php/jurnalbinaedukasi \\ Vol. 11, No. 1, Juni 2018, 36-48}

Kriteria pengujian hipotesis terima $\mathrm{H}_{0}$ jika $t_{\text {hitung }}<t_{\text {tabel }}$ dan tolak $\mathrm{H}_{0}$ jika $t_{\text {hitung }}>$ $t_{\text {tabel }(1-\alpha)}$. Dari hasil perhitungan diperoleh nilai $t_{\text {hitung }}=6,564$ sedangkan $t_{\text {tabel }}=1.740$ (tabel distribusi t) berarti $t_{\text {hitung }}=6.564>t_{\text {tabel }}=1.740$ dengan demikian $\mathrm{H}_{0}$ ditolak dan $\mathrm{H}_{\mathrm{a}}$ diterima maka dapat disimpulkan bahwa "Ada Pengaruh latihan circuit training terhadap peningkatan daya tahan aerobik pemain sepakbola Universitas Bina Darma'”.

\subsection{Pembahasan}

Hasil penelitian yang dilakukan oleh peneliti untuk meningkatkan daya tahan aerobik pada pemain sepakbola Universitas Bina Darma dengan cara diberi latihan circuit training menunjukkan adanya peningkatan. Peningkatan ini dilihat dari hasil $t_{\text {hitung }}=6.564>t_{\text {tabel }}=$ 1.740 dengan demikian menjawab hipotes yang diajukan olehpeneliti yaitu $\mathrm{H}_{0}$ ditolak dan $\mathrm{H}_{\mathrm{a}}$ diterima.

Latihan circuit training yang menunjukkan adanya peningkatan tersebut dilakukan secara berkesinambungan, teratur selama 6 minggu dimana dalam 1 minggu dilakukan 3 kali latihan. Penerapan prinsip-prinsip latihan yang baik maka mendapatkan hasil yang baik. Prinsip latihan tersebut yaitu prinsip kesiapan (Readiness), prinsip individual, prinsip adaptasi, prinsip beban lebih (Overload), prinsip progresif (Peningkatan), prinsip spesifikasi (Kekhususan), prinsip variasi, prinsip pemanasan dan pendinginan (Warm-Up and Cool Down), prinsip jangka panjang (Long Term Training), prinsip berkebalikan (Reversibility), prinsip tidak berlebih (Moderat), prinsip sistematik (Mylsidayu, 2015: 55-64). Latihan circuit training ini disesuaikan dengan kebutuhan dalam olahraga sepakbola. Latihan ini terdiri dari 8 pos yaitu : push up, sit up mount climb, ,cone jump, jumping jack, lunges, leg raises, dan tricep dips.

Daya tahan aerobik seseorang berbeda-beda sehingga ada yang dapat ditingkatkan secara signifikan dan tidak signifikan. Faktor yang mempengaruhi tersebut dipengaruhi beberapa faktor, yaitu (1) faktor internal : genetik, umur, jenis kelamin dan lain-lain, dan (2) faktor eksternal : pola makan, merokok, kurangnya istirahat. Hal ini sependapat dari WHO (2010) yang menyatakan bahwa faktor yang mempengaruhi daya tahan adalah usia, jenis kelamin, aktivitas fisik olahraga, asupan gizi dan status gizi seseorang. Melihat dari faktor-faktor tersebut sebagai pemain sepakbola hendaknya para pemain menjauhi faktor eksternal yang dapat menurunkan performa mereka. 


\section{JURNAL ILMIAH \\ BINA EDUKASI \\ ISSN 1979-8598 \\ http://journal.binadarma.ac.id/index.php/jurnalbinaedukasi \\ Vol. 11, No. 1, Juni 2018, 36-48}

\section{SIMPULAN}

Berdasarkan uraian di atas diperoleh bahwa Ada Pengaruh Latihan Circuit Training terhadap Peningkatan Daya Tahan Aerobik Pemain Sepakbola Universitas Bina Darma. Data hasil perhitungan secara statistic menunjukkan bahwa $t_{\text {hitung }}=6.564>t_{\text {tabel }}=1.740$.

\section{DAFTAR PUSTAKA}

Arikunto, Suharsimi. 2006. Prosedur Penelitian Suatu Pendekatan. Rineka Cipta. Jakarta.

Bompa, TO. 1983. Theory and Methodology of Training, the Key to Athletic Performance. Dubuque, Kendal/ Hunt Publishing.

Depdiknas.(2000).Pedoman dan Modul Pelatihan Kesehatan Olahraga Bagi Pelatih Olahragawan Pelajar. Jakarta: Pusat Pengembangan Kualitas Jasmani.

Irianto, Djoko Pekik. 2002. Dasar Kepelatihan. Yogyakarta.

Irianto, Djoko Pekik,dkk. 2007. Pelatihan Pelatih Fisik Level 1. Jakarta: Asdep Pengembangan

Harsono. 1988. Coaching dan Aspek-Aspek Psikologi dalam Coaching. Jakarta : Depdikbud.

Husein Argasasmita, dkk. 2007. Teori Kepelatihan Dasar. Jakarta: Kementrian Negara Pemuda dan Olahraga.

Kokasih, Engkos. 1993. Olahraga Teknik dan Program Latihan. Jakarta : Akademika Pressindo.

Maksum, Ali. 2012. Metode Penelitian Dalam Olahraga. Surabaya: Unesa University Press2012.

Meilke, Danny. 2007. Dasar - Dasar Sepakbola. PT Intan Sejati. Bandung.

Muhajir. 2004. Pendidikan Jasmani Teori dan praktik SMA Kelas X. Jakarta : Erlangga.

Muhajir. 2007. Pendidikan Jasmani Olahraga dan Kesehatan. Penerbit Erlangga. Jakarta.

Mylsidayu, Apta dan Febi Kurniawan. 2015. Ilmu Kepelatihan Dasar. Bandung: Alfabeta, cv.

Sajoto, Mochamad. 2000. Pembinaan Kondisi Fisik Dalam Olahraga. Jakarta: FPOK - IKIP Semarang. 


\section{JURNAL ILMIAH}

BINA EDUKASI

ISSN 1979-8598

http://journal.binadarma.ac.id/index.php/jurnalbinaedukasi

Vol. 11, No. 1, Juni 2018, 36-48

Sucipto, dkk. 2000. Sepakbola. Departemen Pendidikan Nasional Direktorat Jenderal Pendidikan Dasar dan Menengah Bagian Proyek Penataran Guru SLTP Setara D-III. IKIP Yogyakarta. Yogyakarta

Sugiyono.2011. MetodePenelitianPendidikanKuantitatifKualitatif Dan R\&D. Bandung: Alfabeta

Sugiyono, 2012. Metode Penelitian Pendidikan Pendekatan Kuantitatif, Kualitatif dan R\&D. CV Alfabeta. Bandung.

Suharjana. 2013. Kebugaran Jasmani. Yogyakarta: Jogja Global Media

Sukadiyanto, 2011. Pengantar Teori Dan Metodologi Melatih Fisik. CV Lubuk Agung. Bandung.

Sumosardjono, Sadoso. 1987. Petunjuk Praktis Kesehatan Olahraga. Jakarta : PT. Pustaka Karya Grafika Utama.

Wahjoedi. (2001). Landasan Evaluasi Pendidikan Jasmani. Jakarta: PT Raja Grafindo Persada.

Widiatuti. 2015. Tes dan Pengukuran Olahraga. Jakarta : PT. Rajagrafindo Persada.

WHO. 2010.Global Recommendations on Physical Activity for Health. Switzerland: WHO. 